\title{
USING THE THINK-PAIR-SHARE STRATEGY TO INCREASE STUDENTS' ACTIVE INVOLVEMENT AND TO IMPROVE THEIR SPEAKING ABILITY
}

\author{
Muhammad Lukman Syafii \\ Muhammadiyah University of Ponorogo, Indonesia \\ (s.muhammadlukman@yahoo.com)
}

Received: $15^{\text {th }}$ March 2018; Revised: $25^{\text {th }}$ May 2018; Accepted: $28^{\text {th }}$ June 2018

\begin{abstract}
This study was designed to increase students' active involvement and to improve their speaking ability using Think-Pair-Share Strategy at Muhammadiyah University of Ponorogo. The study was collaborative action research. This study was conducted in one cycle consisting of five meetings using the following procedures: planning, implementing, observing, and reflecting. The data of the study were collected through the observation checklists, field notes, and questionnaire. The subjects were 26-second semester students of Class A. The increase could be seen from the number of students who were categorized as actively involved from only 7 students (29\%) in the preliminary study to 20 students (78\%) of 26 at the end of the study. The improvement of students' speaking ability could be seen from the increasing number of students whose average score was 3, from 7 students $(29 \%)$ of 24 students in the preliminary test to 17 students $(65 \%)$ of 26 students in the final test. Therefore, this strategy is appropriate for the students to increase their active involvement and improve the speaking ability.
\end{abstract}

Key Words: Think-Pair-Share, active involvement; speaking ability

\begin{abstract}
ABSTRAK
Penelitian ini dirancang untuk meningkatkan keaktifan dan kemampuan berbicara mahasiswa dengan menggunakan Berfikir-Berpasangan-Berbagi di Universitas Muhammadiyah Ponorogo. Penelitian ini merupakan penelitian tindakan kelas yang bersifat kolaboratif. Penelitian ini dilakukan dalam satu siklus yang terdiri dari lima pertemuan dengan menggunakan prosedur sebagai berikut: perencanaan, pelaksanaan, pengamatan dan penghayatan. Pengumpulan data dilakukan dengan menggunakan lembar observasi, catatan lapangan, dan kuesioner. Subjek penelitian ini adalah 26 mahasiswa semester 2 kelas A. Peningkatan keterlibatan aktif mahasiswa dapat dilihat dari meningkatnya jumlah mahasiswa yang termasuk dalam kategori aktif yang pada saat penelitian awal hanya 7 mahasiswa (29\%) menjadi 20 mahasiswa (78\%) dari 26 mahasiswa yang masuk pada saat hari observasi pertemuan terakhir. Peningkatan kemampuan berbicara mahasiswa dapat dilihat dari meningkatnya jumlah mahasiswa yang memiliki nilai rata-rata 3, dari 7 orang menjadi 17 orang. Maka dari itu, strategi ini sesuai bagi mahasiswa untuk meningkatkan keterlibatan aktif dan memperbaiki kemampuan berbicara bahasa inggris mereka.
\end{abstract}

Kata Kunci: berfikir-berpasangan-berbagi, keterlibatan aktif, kemampuan berbicara

How to Cite: Syafii., M. L. (2018). Using the Think-Pair-Share Strategy to Increase Students' Active Involvement and to Improve Their Speaking Ability. IJEE (Indonesian Journal of English Education), 5(1), 61-80. doi:10.15408/ijee.v5i1.7679 


\section{INTRODUCTION}

Nowadays, English has been increasingly becoming the medium of communication in every aspect of life, particularly in education domain. As a result, many people learn English as the endeavor to face the global demand. The paramount purpose for them in learning it is to be able to speak. They consider that speaking is the most crucial language skill among other skills. According to Ur (1996), speaking seems intuitively the most important: people who know a language are referred to as speakers of that language, and many if not most, foreign language learners are primarily interested in learning to speak.

In Indonesia, English is a foreign language (Widiati \& Cahyono, 2006). For Indonesian people, English is learned after they mastered their first language. Gebhard (1998) states that English as a foreign language means that English is studied by people who live in places where English is not their first language; English is only taught as a school subject. For this position, many Indonesian people, including students, find several problems in mastering it. They consider that English is as quite difficult to learn and even they think that it is the most difficult one to master.
The appropriate learning strategies, particularly in language learning, will result in students 'success in learning (Awang et al., 2013). It means deciding which learning strategy that suits best for students is essential. However, many English teachers, particularly EFL teachers, do not realize this (Meyer, 2012). For instance, traditional grammar-translation teaching method and textbook oriented teaching practice are still very popular to be used in language classroom for several years (Exley, 2005; Faridi, 2010; Meyer, 2012). Teachers will mostly rely only on students 'textbook or translate the grammar into L1 rather than connecting it with context related with the students 'surrounding. This condition will eventually cause less students involved in the learning process (Meyer, 2012) which will eventually result the learning process become ineffective because they do not learn language by experiencing them (Banegas, 2011). Moreover, the recent learning style that is used in typical language classrooms often focus to make students able to pass the exams, without considering whether they are able to use the language or not (Exley, 2005; Meyer, 2012; Hosni, 2014). Also, most materials given rarely require the students to speak, or if it does, it fails to keep the interaction going in the class, hence, the students tend to keep quiet and shy in 
the class (Meyer, 2012; Hosni, 2014). Teachers mostly focus on elements or materials tested in examinations, such as reading, grammar, and vocabulary, which make students environment to speak limited (Meyer, 2012).

Environment also plays an important role for students to learn a language, including English (Febriyanti, 2007; Meyer, 2012; Hosni, 2014). For instance, learning English can be easier for those who live in English speaking countries, or at least in countries where English is used as a second language. However, learning English can be challenging if the learners are dealing with the fact that English is considered as a foreign language, where people are seldom to use the language for communication, such as in Indonesia (Febriyanti, 2007). It means the opportunity that students get to communicate using English is very limited. This condition is even worsened by teachers who are most likely to use L1 for class management (Hosni, 2014). The use of L1 to teach foreign language will only devalue the foreign language as a mean of communication, which results in demotivating students to use English (Febriyanti, 2007; Hosni, 2014). Additionally, dealing with the fact that most schools in Indonesia have a lot of students in one classroom may also demotivate students to speak using
English. As a result, students will indeed tend to speak using their mother tongue as they do not see any value to speak using the foreign language (Hosni, 2014).

The difficulties in mastering English as a foreign language may be triggered by various factors. Those could be from the English language itself, or from the learners themselves, or possibly from the learning process itself. Obviously, the role of the teacher also plays a crucial effect (Nunan, 1999). For Indonesian people, English is a complex language for it contains various patterns, the unique spelling, and pronunciation. It is said that English is badly spelled (Literaryresearch, 2001).

Focusing on the language learners, the characteristics of the learners' personality give beneficial help in gaining the success of learning English. Lightbown and Spada (1999) state that other factors, known as learners' personality characteristics, such as intelligence, aptitude, motivation, and attitudes are generally considered to be relevant to language learning. The learners with introvert character and having low selfconfidence probably feel great difficulty in practicing their English, while the extrovert ones will practice their English confidently. 
In gaining the successful learning process, the environment where the learners learn English probably plays a significant role. Dulay, et al. (1982) suggests that exposing the students to the formal environment would just focus on the conscious acquisition of rules and forms. It may restrict them to be able to communicate naturally and effectively. While exposing them to the natural environment where the focus of the learning is on the content of communication possibly appears to enhance the development of communication skills.

The objective is to make the students able to communicate in English fluently and accurately through various activities, contexts, and situations at Muhammadiyah University of Ponorogo. Since their first semester, the students are encouraged to speak English through various teaching and learning activities.

Based on the data of the preliminary study derived from the interview with the teacher and students, classroom observation and questionnaires, it was found that there are several problems they encounter in their speaking class so that the result is not satisfactory yet because of some reasons. Many students still have problems in expressing their verbal language that their speaking ability was poor. Based on the data from their speaking score in the preliminary test, it was found that out of the 24 students joining the test, only 7 students $(29 \%)$ achieved average score 3 which is considered good. The score used range from 1 to 5 .

One of the problems that seem to restrain their speaking is lack of selfconfidence. Based on the result of the questionnaire, it was found that the majority of the students still feel reluctant, nervous and shy to speak, especially when they are asked to speak in front of their friends knowing that they are heterogeneous-coming from different characters, the background of education and families. It seems that they seldom cooperate with one another. This condition also affects their active involvement during their speaking class. Very little of them are willing to ask for clarification to their teacher, respond to or answer the teacher's instruction and question, do the task given by having an active discussion with their peer/group, help or ask for help from each other and answer their friends' question actively. It was found that out of 26 students, there were only 7 students $(27 \%)$ who were categorized as active students.

Think-Pair-Share (shortened as TPS) strategy is one of the cooperative learning methods that encourage 
individual participation. The strategy is designed to influence the students' interaction style. It was first proposed by Frank Lyman and his associates in Maryland University in 1981 (Ledlow, 2001). Think-Pair-Share is as an effective way to make various atmospheres in the classroom discussion. Its assumption is that all classroom discussions need management to control the whole class and the procedure used is enabling to give the students more opportunities to think, to respond and to help each other (Trianto, 2007). Its purposes include providing 'think time' to increase the quality of students' responses. They become actively involved in thinking about the concepts presented in the lesson, they become more critical and willing to participate since they do not feel the peer pressure involved in responding in front of the whole class.

This TPS consists of three phases. The first phase is Thinking phase. In this phase, the teacher poses one openended question or challenging problem related to the lesson. Then, the students are asked to use several minutes to think of the possible answer or solution individually. The 'Think Time' incorporates the important concept of 'wait time'. It allows all students to develop answers. This is important because this 'thinking time' gives students a chance to start to formulate answers by retrieving information from long-term memory. It becomes a powerful factor in improving their responses to questions or problems.

By having this phase, the students are triggered to develop their thinking skill or critical thinking. Raghunathan (2001) states that thinking is as the highest activity of a man. The benefits of developing thinking ability are manifold. By developing one's thinking skill; one can make achievements, can become successful, can shine in social life, and can attain emotional, social and economic maturity.

The second phase is Pairing phase. This phase is as the following actions after the thinking activity. In this phase, the students are asked to be in pair with a cooperative group member or neighbor sitting nearby to discuss what they have thought. This is important because students start to construct their knowledge in these discussions and also to find out what they do and do not know. Ibe (2009) states that this activity could force the students to use their metacognition to examine their thinking, analyze their position, and explain their point of view to their classmate. In this paired interaction, each of the students reveals his/her personal answer or solution to be united with his/her pair. Normally, the 
time allotment is about four or five minutes to do this phase.

The merit of this phase is to provide the opportunity to the students to help each other with the cooperation in solving the problem given that eventually, their social quotient improves. In addition, Tsui (in Nunan 1999) states that this phase also can be a solution to overcome reluctant students since they have the opportunity to rehearse their responses in small groups or pairs before being asked to speak up in front of the whole class.

The third phase is Sharing phase. In this phase, the teacher solicits the pair to share the answer or the solution to the whole class. The other pairs may give a comment or additional input to others. Ibe (2009) said that by asking them to share the information with the entire class, students would be able to evaluate themselves while gathering information from other classmates. The teacher would also have the opportunity to evaluate the students' understanding based on the content of the discussions.

In this case, the students are much more willing to respond after they have had a chance to discuss their ideas with a classmate because if the answer is wrong, the embarrassment is shared. Also, the responses received are often more intellectually concise since students have had a chance to reflect on their ideas. Eventually, this can enhance the students' confidence to speak publicly (Arends, 1997).

There are several studies focusing on the implementation of learning method, particularly on Think-PairShare strategy. Wafi (2011) made the study on Using the Think-Pair-Share Strategy to Increase Students' Active Involvement and to Improve Students' Speaking Ability at Islamic University of Malang. The result shows that students, who have the opportunity to work cooperatively, learn faster and more efficiently. They also have greater retention and feel more positive towards the learning experience. Besides, they become more active in involving themselves in the teaching and learning activities (New Horizon, 2005).

Pattiiha (2006) made a study on improving the implementation of the learning of beginning reading among the second-year students at SDN Sumbersari by using the Think-PairShare strategy. Based on her findings, she concluded that it could be applied effectively to improve the implementation of the beginning reading at the planning, implementation, and evaluation stage.

In addition, Buharsa (2008) also made a study on improving the reading 
comprehension of the second-year students of MTsN Sanggau through the Think-Pair-Share strategy. Based on her findings, her students' reading comprehension gradually improved. The use of Think-Pair-Share increasingly helps and motivates the students to gain a better understanding of the text.

Another study conducted by Juhari (2009) on improving the reading comprehension skills of the eleventh graders of MA Darul Lughah Wal Karomah Kraksan Probolinggo through the Think-Pair-Share Strategy. Based on the result of his study, it was found that his students' average score in reading improved and their active participation was increased. The number of students who shared, asked and answered questions were increased. This occurred since the strategy encouraged students to share ideas, asking questions as well as answering questions between pairs.

With any previous studies on improving speaking ability using the Think-Pair-Share strategy, this study would like to implement this strategy at Muhammadiyah University of Ponorogo as a solution for the problem faced by students in their speaking class. He believed that the strategy will be more powerful when it is implemented in such class since, in the pairing and sharing session, the students will automatically need oral language to do the sessions. They will automatically use several utterances related to asking and giving an opinion, saying agreement and disagreement, giving objection and addition, and the like. Also, in elaborating their ideas, they will automatically improve their speaking ability.

\section{METHOD}

The design of this research was the classroom action research. It took two cycles each of which has four meetings. This design dealt with coping with the problems found in the classroom. The research step was started from the problem found by the teacher in his/her classroom. Latief (2009) states that classroom action research for English learning is aimed at developing a certain instructional strategy to solve practical instructional problems in English classroom. This research is designed to apply the Think-Pair-Share strategy to solve the problem in speaking class.

In conducting this action research, the researcher collaborates with one collaborator. The collaborator is the lecturer who teaches in the speaking class. Based on the agreement, the researcher acted as a teacher implementing the Think-Pair-Share strategy and the collaborator acted as 
the observer. There are 26 participants in conducting this research.

\section{The Instrument Used in this Study}

Before conducting the research, the researcher prepared the research instruments such as observation checklists, field notes, questionnaires, and speaking test. Those research instruments were used to observe and record the data during the process of implementing the Think-Pair-Share strategy.

The observation checklists

There were two kinds of observation checklists used in this research. The first was used to observe the students' response toward the teacher's instruction in each meeting. This observation checklist was consisted of five items completed with columns to put a check and write comments. The observer, through her observation, put a check on each item and wrote comments as well.

The second observation checklist was used to observe the students' involvement during the teaching and learning activities in each meeting. There were 5 indicators provided in the observation checklist; they were (1) asking questions for clarification frequently, (2) responding to and or answering the teacher's instruction and questions, (3) doing the task by having active discussion with his/her peer or group, (4) helping and or asking for help from each other, and (5) answering their friend's question actively.

The observer, through her observation, put a check $(\sqrt{ })$ on each indicator. From those indicators, the observer then categorized the students into four categories: The first category was Very Active (VA); it was for the students who met all of the five indicators. The second was Active (A); it was for students who met four of the indicators. The third was Active Enough (AE); it was for the students who met two or three indicators, and the fourth category was Not Active (NA); it was for students who met one or none of the indicator. Then to achieve the criteria of success of the students' active involvement was gained from the result of the percentage of Very Active added by the percentage of Active (VA + A).

Field notes

Field notes were used to observe everything happened, which was not covered in the observation checklist, during the teaching and learning process in each meeting. The observer made notes on the problems encountered to both the teacher and students. It could be notes on students' difficulties during the lesson such as 
vocabulary, grammar and the like. The field note was also completed with observer's comment that the observer might write any comment related to the teaching and learning activities in each meeting.

The questionnaires

The questionnaires were used to gain the data from the students' personal judgment on the implementation of the strategy and its benefits they experienced. It consisted of 15 questions which were divided into two domains; question numbers 1 to 9 related to students' responses to the use of the Think-Pair-Share strategy and the benefits in improving their speaking ability while question numbers 10 to 15 related to students' involvement toward the teaching and learning activities using the strategy. In dealing with the questionnaire, the researcher gave one questionnaire to each student and asked them to put a cross ( $x$ ) on the column "Yes" or "No". In addition, the questionnaire was completed with empty blank that the students might write down their opinion and comment or suggestion about the strategy.
Speaking Test

The formula of computation used was the whole scores the students achieved in each element were added and then divided into 4 and its result became the final score. And the criterion of success used in this research was if $60 \%$ of students achieved average score 3 which is described as Good.

The collaborator, who was equipped with those research instruments, observed the researcher and students in the teaching and learning activities during the implementation of the strategy.

The design of action research used in this study was a cyclical process adapted from the model proposed by Kemmis and McTaggart (cited in Koshy 2007). It consists of four main steps: planning the action, implementing the action, observing the action, and reflecting the action (See Figure 1). 


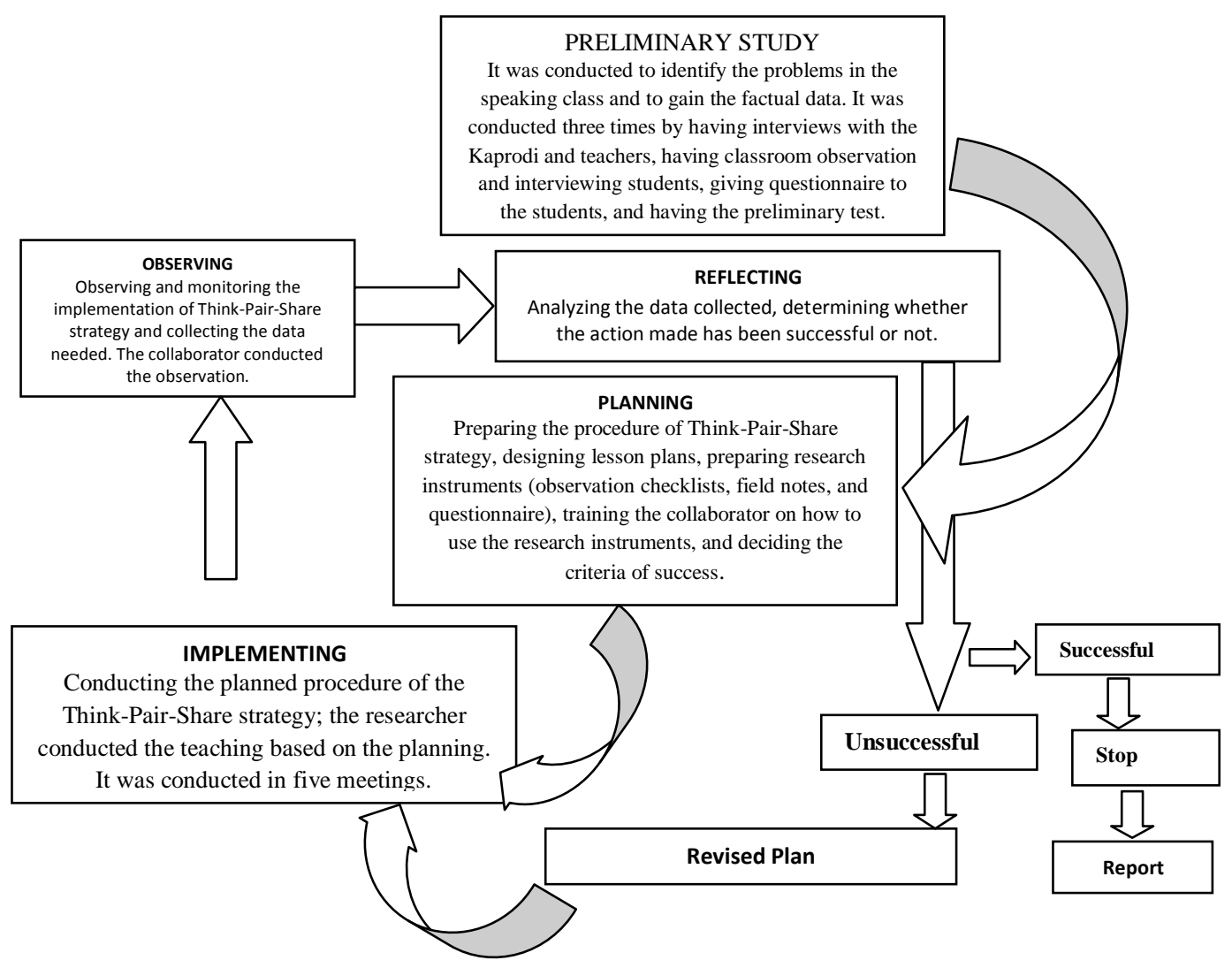

Figure 1. adapted from the model proposed by Kemmis and McTaggart (cited in Koshy 2007: 4)

\section{FINDINGS AND DISCUSSION}

\section{Findings}

\section{The Data Analysis}

The Number of Participants, Students' Active Involvement

The data attained from the observation checklist for students' involvement was different from each meeting. There were 26 participants in this study. In the first meeting, there were only 2 of 26 students (2\%) who were considered as very active students. It was indicated by their accomplishment in reaching all the five indicators. There were 4 students $(16 \%)$ who were considered as Active since they accomplished four of the five indicators there were 8 students (31\%) being considered as Active Enough and there were 12 students (47\%) who were not Active. For this meeting, the students' involvement seemingly did not show any significance. 
In the second meeting, the students' involvement showed better compared to the first meeting. Based on the data from the observation checklist, it was found that 6 out of 26 students (24\%) were considered as very active. There were also 6 students (24\%) who were considered as active, 6 students (24\%) were included in active enough and 8 students (31\%) were considered as not active. For this meeting, there were only $48 \%$ of the students who were considered in the active involvement as stated in the criteria of success which was $75 \%$. So, the students' active involvement did not meet the criteria for success. However, it showed significantly better compared to the result of the first meeting.

In the third meeting, after learning from the previous meetings, the researcher conducted his teaching activities more meticulous by giving them more motivation, attention, and control.

As the result, the students' involvement showed better than the previous ones. In this meeting, there were 2 students absent due to a health problem. So, there were 24 students joined in the classroom activities. Based on the data gained from the observation checklist for students' involvement, it was found that there were 7 of them $(30 \%)$ who were included as very active students, 9 of them (38\%) were considered as active, 5 of them (21\%) were active enough and 3 of them (13\%) were considered as not active students. From the data, the active involvement achieved $68 \%$. In this meeting, the result of students' involvement still did not meet the criteria for success. It needed $7 \%$ more to reach $75 \%$ which was stated as the criteria for success.

In the fourth meeting, of the 26 students, all of them took part in the teaching and learning activities. Based on the data gained from observation checklist for students' involvement, there were 8 students $31 \%$ ) who accomplished the five indicators that being considered as very active students. 12 students (47\%) were considered as active, 3 students (11\%) were active enough and 3 of them $(11 \%)$ were not active. From the data, it was found that the number of students who were considered as active in involving themselves in the teaching and learning activities achieved the criteria for success. It was proven by the percentage of very active students (31\%) added by the percentage of active students $(47 \%)$ achieved $78 \%$ which was more $3 \%$ than the percentage of criteria of success which was $75 \%$.

Another data was based on the observation checklist for students' responses and field notes. From the 
data, it was found that the teacher was good at engaging the students in the activity that the students showed their enthusiasm. The thinking time was working perfectly and most of the students were actively involved in the discussion by using English. Very few of them were using Bahasa Indonesia. The sharing session was also done well since each student got the opportunity to talk and express their ideas. The domination of the strong students was also less. It is shown in Table 1.

The findings above were also supported by the result of questionnaires. The questionnaire used consisted of 15 questions with two optional answers: "Yes" and "No". Those 15 questions were divided into two focuses: questions number 1 to 9 relates to students' feeling towards the strategy used and their speaking progress. The questions number 10 to 15 relates to students' involvement in the teaching and learning activities using think-pair-share strategy. The questionnaire was distributed to the students after accomplishing the fourth meeting. All of the 26 students took part in filling the questionnaires given.

Based on the data from the questionnaire, for the first question was about students' feeling toward the strategy having been used; it was found that 26 students $(100 \%)$ gave positive response toward the use of the ThinkPair-Share strategy. They felt happy with the use of strategy in their speaking class. The second question was about their motivation to speak English during the use of the strategy. Of the 26 students, all of them $(100 \%)$ felt motivated to speak English. The third question was about their confidence-whether their confidence increase or not through the use of the strategy. From 26 students, there were 23 students (89\%) felt more confident to speak English and 3 of them (11\%) felt their confidence was not increasing.

Table 1. Students' Involvement during the Teaching and Learning Process in Cycle One

\begin{tabular}{|c|c|c|c|c|c|c|c|c|c|c|c|c|c|c|c|c|}
\hline \multirow{2}{*}{$\begin{array}{l}\text { Meeting } \\
\text { Categories }\end{array}$} & \multicolumn{4}{|c|}{ First meeting } & \multicolumn{4}{|c|}{ Second meeting } & \multicolumn{4}{|c|}{ Third meeting } & \multicolumn{4}{|c|}{ Fourth meeting } \\
\hline & VA & A & $\mathrm{AE}$ & NA & VA & A & $\mathrm{AE}$ & NA & VA & A & $\mathrm{AE}$ & NA & VA & A & $\mathrm{AE}$ & NA \\
\hline Students & 2 & 4 & 8 & 12 & 6 & 6 & 6 & 8 & 7 & 9 & 5 & 3 & 8 & 12 & 3 & 3 \\
\hline$\%$ & 8 & 16 & 31 & 47 & 24 & 24 & 24 & 31 & 30 & 38 & 21 & 13 & 31 & 47 & 11 & 11 \\
\hline $\begin{array}{l}\text { Total } \\
\text { percentage } \\
\text { of VA+A }\end{array}$ & \multicolumn{4}{|c|}{$24 \%$ (6 students) } & \multicolumn{4}{|c|}{$48 \%$ (12 students) } & \multicolumn{4}{|c|}{$68 \%$ (16 students) } & \multicolumn{4}{|c|}{$78 \%$ (20 students) } \\
\hline
\end{tabular}

Where: - VA stands for very active - A stands for Active - AE stands for Active Enough NA stands for not Activ 
The next question was about the benefit of thinking time in helping the students to be able to speak English. There were 25 students (96\%) got helped by the giving of thinking time and 1 of them $(4 \%)$ did not experience the benefit of the giving of thinking time. The fifth question was about the benefit of pairing session in helping the students to find the answer or the solution of the question or the problem is given. Of the 26 students, there were 25 of them (96\%) found that the pairing session very helpful for them to find the possible answer of the problem given and there was only 1 student (4\%) did not get the help from the pairing session.

The sixth question was about the giving time to work in a pair in helping the students to be ready and more confident in revealing their ideas. Of the 26 students, all of them (100\%) found that working in the pair was really helpful to make them ready and more confident to reveal their ideas. The next question was about the benefits of sharing session. 23 students (89\%) agreed that by giving time to share, they felt easier to reveal their ideas and 3 of them (11\%) found that they did not get the benefit of the giving time to share.

The next question was about whether the students still feel nervous or not when they present or share their idea with the whole class. Of the 26 students, it was found that 18 of them (70\%) still felt nervous when they were asked to present or share their ideas to the whole class and 8 of them (30\%) found that nervousness was no a problem from them. The ninth question was about their English progress. 23 students (89\% of them) confessed that their English got more progress and the rest 3 (11\%) found their English did get any progress.

The question number 10 was about the students' attitude toward their teacher about questioning for clarification. There were 9 students (35\%) answered that they often ask a question for clarification to their teacher while 17 students (65\%) answered that they seldom ask a question for clarification to their teacher. The next question was about whether the students respond to their teacher's instruction and questions; from 26 students, 24 of them (93\%) gave response and or answer to their teacher's instruction and questions, while 2 of them (7\%) did not give response or answer to their teacher's instruction or question.

The question number 12 was about whether the students did the task given by having an active discussion with their peer/group. There were 25 
students (96\%) confessed that they had an active discussion with their peer/group when they were given task and only 1 of them (4\%) did not have active discussion towards the task given. The $13^{\text {th }}$ question was about whether they helped or asked for help from one another. All of them $(100 \%)$ helped or asked for help from one another.

The next question was about whether the students answer their friends' question actively. From their answer, it was found that 18 of them $(70 \%)$ gave an answer to their friends' question actively and the rest $8(30 \%)$ did not answer their friends' question actively. And the last question was about a general question whether the students felt more motivated and active in involving themselves in the learning activity in the classroom. From 26 students, all of them $(100 \%)$ confessed that they felt more motivated and active in involving themselves in the learning activity in the classroom.

\section{The Students' Speaking Scores}

In having this on-going assessment, the collaborator assessed the students by focusing on some students in each meeting. First of all, the assessment was focused on the lower studentsreferring to their speaking score attained in the preliminary test which achieved under average 3 . It was conducted so because it was quite difficult to assess them and more time was also needed. In assessing them, the collaborator observed the students who were focused on when they were speaking during the pairing session and obviously when they were in sharing session.

In the next meetings, the collaborator gave the lists to the researcher about the students to be focused on. Then, the researcher focused on the listed students by pointing them to be representative of the group or the whole class to present or share their ideas with the whole class during the sharing session. In the last meeting, both the researcher and collaborator really focused on the very low students in they endeavor to gain the fix speaking score. There were 8 students (Students number 6, 7, 15, 19, 20, 21, 24, 26) in that meeting; the researcher becoming the teacher gave the each listed students with questions. It was like an interview but conducted towards the whole class.

Based on the data from the students' final speaking test, of the 26 students, it was found that there were 17 of them (65\%) achieved average score 3 and there were 9 students (35\%) achieved underscore 3. Comparing to the students' speaking score attained in their preliminary test which there were 
only 7 students (29\%) who achieved average score 3 and there were 17 students $(71 \% /$ who achieved score under than 3, the students' speaking ability improved that was indicated by their final score. In their preliminary test, the students who achieved average score 3 were only $29 \%$ meanwhile there were $65 \%$ of students who achieved average score 3 .

In terms of categorizing the students' speaking ability; there were five categories for their speaking ability. The first category was an excellent speaking ability which the grade scores 5. Of the 26 students, there were any students whose speaking ability was categorized as excellent since their score did not achieve 5. The next category was very good which grade scores vary from 4 to 4.9. For this category, there were 5 students who achieved score average 4; two students (number 2 and 25 ) achieved score 4.25 , two students (number 1 and 23) achieved score 4.5, one student (number 3 ) achieved score 4.75 .

The third category was good which the grade score 3 to 3.9. Students whose speaking ability included in this category were 12 students; five students (number 4, 5, 9, 13, 14) achieved score 3, two students (number 8 and 16) achieved score 3.25, three students (number 10, 17, 22) achieved score 3.5, two students (number 11,12) achieved score 3.75 .

The next category was a fair speaking ability which the grade scores 2 to 2.9. There were 9 students who included in this category; two students (number 20,24) achieved score 2, three students (number 15, 19, 21) achieved score 2.25, three students (number 6, 7, 26) achieved score 2.5 , and one student (number 18) achieved score 2.75. The last category was a poor speaking ability which the grade scores 1 to 1.9 . For this category, none of the students was included in this category.

Table 2. The Comparison of Score between The Preliminary Test and Final Speaking Test

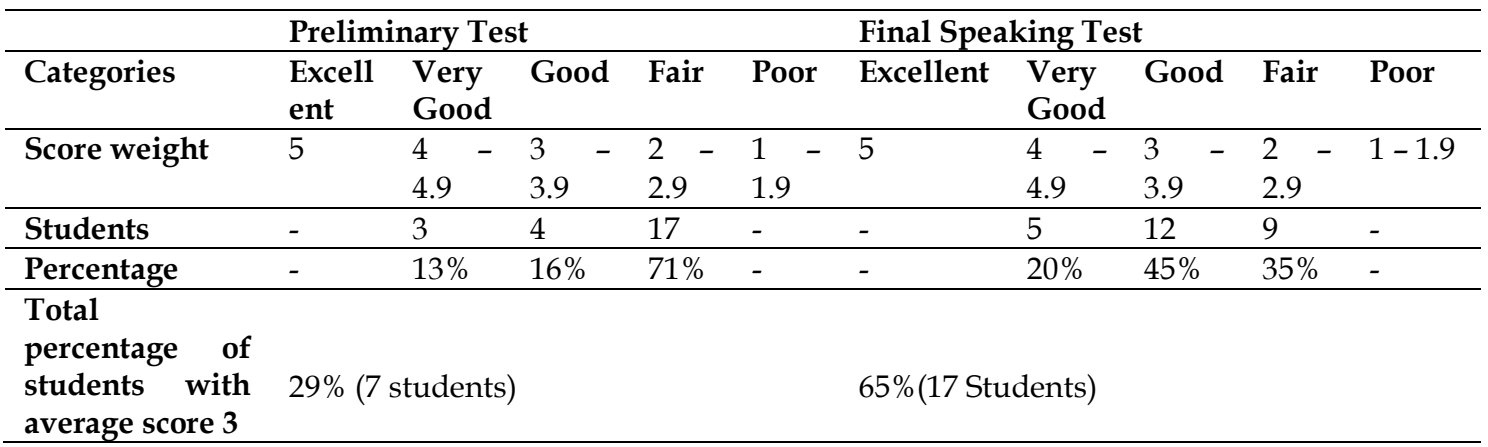


Related to field notes), students encountered several problems that restricted their speaking. Those problems were in terms of their limited vocabulary mastery, fluency, pronunciation, and content. Since the topics of the discussion given were quite difficult for them, the difficult vocabulary items were found such as penyuluhan, razia, memberantas, daerah terpencil, pandang bulu, pendidikan seumur hidup, mencontek, bocoran, keguguran, cacat fisik, cinta tak harus memiliki, kesan pertama begitu menggoda, and gengsi dong.

In terms of pronunciation, the students seemed to get difficulty in pronouncing the words "suitable, swimsuit, pageant, although, knowledge, honesty, taught, and thought. They pronounced "suitable" as "swiitebl", Swimsuit as swimsuwiit", pageant as pegnt, although as olthoug, knowledge as knolij, honesty as honisti, taught as taugh, and thought as though. They also troubled in pronouncing suffixes "ed" for regular verb past forms and "s/es" for plural or verb1. They pronounced laughed as laughd, kissed as kissd, needed as need, and many more. It seemed that they did not know that suffix "ed" could be pronounced into three pronunciations $-/ \mathrm{id} /, / \mathrm{t} /$, and /d/.
In terms fluency, many of the students frequently used "emmm" when they hesitated or thought of the words they wanted to say even for the Javanese students, they twisted to say in their L1 "opo or iku lo" instead of saying "what or I mean" as their way to make their hesitation subtle. It seemed that they did not have any idea about strategic competence and also fillers expression as the solution to gain better fluency and to decrease their hesitation.

Another problem they encountered was the use of expressing agreeing and disagreeing, asking and giving an opinion. They often said "I am agree" instead of "I agree", are you agree with me" instead of "do you agree with me", and "what your opinion about...." instead of "what is your opinion about...".

\section{Discussion}

The findings of the study revealed that the good procedures of implementing the Think-Pair-Share strategy in teaching and learning of speaking consist of six major steps: (1) arousing students' motivation, activating students' background knowledge,

$$
\text { posing }
$$
problem/question, (4) giving students "thinking time" to think of the possible answer/solution, (5) asking them to be in pair and discuss the solution with 
their pair, (6) asking them to share the answer to the group or the whole class. This was related to Cooperative Learning (CL), an instructional strategy which focuses on student, called student oriented. This method is based on the relationship between motivations, interpersonal relationship towards working cooperatively to cope with the problem of learning. It involves a small heterogeneous group working together toward a common goal. In this method, the students work together in four up to six-member teams to master the material initially presented by the teacher (Slavin, 2006).

In addition, the findings of the study indicated that the Think-PairShare strategy was successful in increasing students' active involvement and improving students' speaking ability. The increase could be seen from the number of students who were categorized as actively involved from only 7 students $(29 \%)$ in the preliminary study to 20 students (78\%) of 26. The improvement of students' speaking ability could be seen from the number of students whose score achieved average 3 were 7 students (29\%) of 24 students in the preliminary test, while in their final speaking score were 17 students $(65 \%)$ of 26 students who achieved average score 3. Kagan (in Ghaith 2003) states that cooperative language learning has been proclaimed as an effective instructional strategy in promoting the cognitive and linguistic development of learners of English as a Second Language (ESL) or English as a Foreign Language (EFL). Its procedure is designed to activate the students through inquiry and discussion in a small heterogeneous group-the members are varied whether from the sex, ability and social background. By having a small heterogeneous group, the students are expected to be able to accept their differences to maximize their own and each other's learning (Johnson \& Johnson, 1991).

\section{CONCLUSIONS}

With the research findings, it can be concluded that the Think-Pair-Share strategy has proved very effective to increase students' active involvement and to improve their speaking ability of the second-semester students of Muhammadiyah University of Ponorogo.

The steps of the implementation of the Think-Pair-Share strategy are divided into three activities. The first is pre-activity which covers (a) arousing students' motivation by having several games, (b) activating students' background knowledge by showing some pictures or playing video, (d) asking them several questions related to the pictures or video given. The second is whilst activity; it covers (e) posing an 
open-ended question, (f) providing time to students to think about the possible answers, (g) assigning them to sit in pair, (h) asking them to discuss their own answer with their pair, (i) asking them to share their answers to the group or to the whole class. The third is post-activity; it covers $(j)$ giving feedback to the discussion, (k) asking the students to draw a conclusion, and (l) giving them follow-up activity.

The findings of the research prove that the Think-Pair-Share strategy has been successful in increasing students' active involvement and improving their speaking ability as well. So, it is advisable to implement the strategy in coping with the problems found in their speaking class.

\section{REFERENCES}

Arends, R I. (1997). Introduction to Classroom Instruction and Management. New York: McGrawHill.

Awang, M. et al. (2013). Effective Teaching Strategies to Encourage Learning Behavior. IOSR Journal of Humanities and Social Science 2 (8) Pp. 35-40.

Banegas, D. (2011). Using Letters to Tell Stories in the EFL Classroom. English Teaching Forum, Argentina. 4 (49) Pp. 24-29.
Buharsa, E. (2008). Improving the Reading Comprehension of the Second Year Students of MTsN Sanggau through Think-Pair-Share strategy. Unpublished Thesis. Malang: State University of Malang Press.

Dulay, H., Burt, M., \& Krashen, S. (1982). Language Two. New York: Oxford University Press.

Exley, B. (2005). Learner Characteristics of Asian' EFL Students: Exceptions to the =Norm'. Proceeding of Joint National Conference AATE \& ALEA, Gold Coast, Australia. Pp. 1-16.

Faridi, A. (2010). The Development of Context-Based English Learning Resources for Elementary Schools in Central Java. Excellence in Higher Education. 1 \& 2 (1) Pp. 2330 .

Gebhard, J. G. (1998). Teaching English as a Foreign or Second Language: A Teacher Self-development and Methodology Guide. Michigan: the Michigan University Press.

Ghaith, G. (2003). Effects of the Learning Together Model of Cooperative Learning on English as a Foreign Language Reading Achievement, Academic SelfEsteem, and Feelings of School Alienation. Bilingual Research Journal, 27:3 Fall 2003.

Hosni, S. (2014). Speaking Difficulties Encountered by Young EFL Learners. International Journal on Studies in English Language and Literature (IJSELL). 6 (2) Pp. 22-30. 
Ibe, H. N. (2009). Metacognitive Strategies on Classroom Participation and Student Achievement in Senior Secondary School Science Classrooms. Science Education International Vol.20, No.1/2, December 2009, 25-31. (E-mail: Helen_ibe@yahoo.com).

Juhari. (2009). Improving the Reading Comprehension Skills of the Eleventh Graders of MA Darul Lughah Wal Karomah Kraksan Probolinggo through Think-Pair-Share Strategy. Unpublished Thesis. Malang: State University of Malang Press.

Johnson, D. W. \& Johnson, R. T. (1991). Learning Together and Alone: Cooperative and Individualistic Learning. Boston: Allyn and Bacon.

Koshy, V. (2007). Action Research for Improving Practice: A Practical Guide. London: Paul Chapman.

Latief, M. A. (2009). Penelitian Kuantitatif dan Kualitatif. Malang: State University of Malang.

Ledlow, S. (2001). Using Think-PairShare in the College Classroom. (Online)

Http://clte.asu.edu/active/using tps.pdf. Accessed on May 20, 2010).

Lightbown, P.M. \& Spada, N. (1999). How Languages are Learned ( Revised ed.) Oxford: Oxford University Press.

Literary-research. (2001). Why English Spelling is so Bad?. (Online) http://literacy- research.com/?p=207 Accessed on January 7, 2011.

Meyer, D. (2012). Broadening Language Learning Strategies for Asian EFL Students. Language Education in Asia. 3 (2) Pp. 243-251.

New Horizon, (2005). Cooperative Learning. (Online) Http://www.newhorizons.org/st rategies/cooperative/front_coope rative.htm Accessed on December 20, 2010.

Nunan, D. (1999). Second Language Teaching $\mathcal{E}$ Learning. Boston: Heinle \& Heinle.

Pattiiha, H. (2006). An Application of the Think-Pair-Share Strategy to Improve the Implementation of the Learning of Beginning Reading Among Second Year Students at SDN Sumbersari II Malang. Unpublished Thesis. Malang: State University of Malang Press.

Raghunathan, A. (2001). How to Improve Your Thinking Skill. (Online) (http:/ / www.psychology4all.com /thinking.htm) Accessed on January 7, 2011.

Slavin, R. E. (2006). Educational Psychology: Theory and Practice. (8th ed.). Boston: Allyn and Bacon Publishers.

Trianto. (2007). Model Pembelajaran Terpadu dalam Teori dan Praktek. Jakarta: Prestasi Pustaka. 
Ur, P. (1996). A Course in Language Teaching: Practice and Theory. Cambridge: Cambridge University Press.

Widiati, U. \& Cahyono, B. Y. (2006). The Teaching of EFL Speaking in the Indonesian Context: The State of the Art. Bahasa dan Seni, Tahun 34, Nomor 2, Agustus 2006.
Wafi, A. (2011). Using the Think-PairShare Strategy to Increase Students' Active Involvement and to Improve Students' Speaking Ability at Islamic University of Malang. Unpublished Thesis. Malang: State University of Malang Press. 